\title{
Pengaruh Perilaku Phubbing terhadap Berkurangnya Intensitas Komunikasi Keluarga pada Masa Pandemi Covid-19
}

\author{
Ayustia Puspita Handayani ${ }^{{ }^{*}}$, Husnita ${ }^{2}$ \\ ${ }^{12}$ Universitas Gunadarma \\ Alamat: Jl. Margonda Raya No. 100, Depok (16424), Indonesia \\ e-mail: ayustiaph@gmail.com
}

\section{The Effect of Phubbing Behavior on the Reduced Intensity of Family Communication during the Covid-19 Pandemic}

\begin{abstract}
The Covid-19 pandemic has forced the government to implement a "stay at home" policy that requires people to reduce activities outside the home. The impact of this policy is that technology cannot be separated from the grip, causing phubbing behavior in the family environment. The purpose of this study was to determine whether there was an effect of phubbing behavior on the reduced intensity of family communication during the Covid-19 pandemic in the city of Jakarta. This study uses the Theory of Technological Determinism. The method used is descriptive quantitative, purposive sampling and data collection through questionnaires with a sample of 400 respondents. The results of the hypothesis test state that the value of sig. on the variable phubbing behavior of $0.000<0.005$ and tcount 19,053 > ttable 1,984 so that Ho is rejected and Ha is accepted and from the results of the coefficient of determination (R2) an $R$ Square value of 0.477 means that phubbing behavior affects the reduced intensity of family communication during the Covid-19 pandemic in the city of Jakarta by $47.7 \%$. This result shows that the intensity of family communication during the Covid-19 pandemic is reduced due to the busyness of each family member with activities that are all technological. This is in accordance with the theory of Technological Determinism that the media is the main factor that most influences other things. The use of technology allows humans to be amputated from their duties and functions, both physically and mentally which causes the loss of dignity (dehumanization) as social beings.
\end{abstract}

Keywords: phubbing; intensity of family communication; smartphones; technological determinism

\begin{abstract}
ABSTRAK
Pandemi Covid-19 membuat pemerintah menerapkan kebijakan "di rumah aja" yang mengharuskan masyarakat mengurangi aktivitas di luar rumah. Dampak dari kebijakan ini adalah tidak lepasnya teknologi dari genggaman sehingga memunculkan perilaku phubbing di lingkungan keluarga. Tujuan penelitian ini adalah untuk mengetahui apakah terdapat pengaruh perilaku phubbing terhadap berkurangnya intensitas komunikasi keluarga saat pandemi Covid-19 di Kota Jakarta. Penelitian ini menggunakan Teori Determinisme Teknologi. Metode yang digunakan adalah kuantitatif deskriptif, purposive sampling dan pengumpulan data melalui kuesioner dengan jumlah sampel 400 responden. Hasil uji hipotesis menyatakan bahwa nilai sig. pada variabel perilaku phubbing sebesar 0,000 $<0,005$ dan thitung 19,053 > ttabel 1,984 sehingga Ho ditolak dan Ha diterima dan dari hasil koefisien determinasi (R2) didapat nilai R Square 0,477 yang berarti bahwa perilaku phubbing berpengaruh terhadap berkurangnya intensitas komunikasi keluarga pada masa pandemi Covid-19 di kota Jakarta sebesar 47,7\%. Angka tersebut menunjukkan bahwa intensitas komunikasi keluarga selama pandemi Covid-19 berkurang dikarenakan kesibukan masing-masing anggota keluarga dengan kegiatan yang menjadi serba teknologi. Hal ini sesuai dengan teori Determinisme Teknologi bahwasanya media adalah faktor utama yang paling mempengaruhi hal lainnya. Penggunaan teknologi memungkinkan manusia teramputasi dari tugas dan fungsinya, baik secara fisik maupun mental yang menyebabkan hilangnya harkat (dehumanisasi) sebagai makhluk sosial.
\end{abstract}

Kata kunci: phubbing; intensitas komunikasi keluarga; smartphone; determinisme teknologi 


\section{LATAR BELAKANG}

Pandemi Covid-19 memberikan berbagai dampak di setiap sektor hingga akhirnya pemerintah memutuskan untuk menerapkan kebijakan yang membatasi aktivitas masyarakat seperti PSBB (Pembatasan Sosial Berskala Besar), dan di rumah aja. Kebijakan tersebut membuat para pelajar dan mahasiswa harus Belajar dari Rumah (BDR) sedangkan pekerja menerapkan Work From Home (WFH) (Kuncara et al., 2020)

Kebijakan BDR dan WFH memberikan dampak dan pengaruh terhadap peningkatan penggunaan teknologi di Indonesia. Menurut Asosiasi Penyelenggara Jaringan Internet Indonesia (APJII) peningkatan tersebut dikarenakan adanya kenaikan traffiic internet yang mencapai angka 15-20\% dimasa pandemi Covid-19 (CNBC Indonesia, 2020). Akibatnya digital tools seperti pendidikan online, media sosial, belanja online dan pertemuan virtual mengalami kenaikan jumlah pengguna (Sebayang, 2020).

Peningkatan jumlah penggunaan jasa internet dan operator seluler di masa pandemi Covid-19 juga berdampak terhadap peningkatan penggunaan perangkat teknologi seperti smartphone (Maulana, 2020). Pada masa pandemi Covid-19, smartphone adalah alat komunikasi utama dalam kegiatan Belajar dari Rumah (BDR) dan Work From Home (WFH) yang mana kebijakan tersebut berdampak pada naiknya intensitas penggunaan smartphone dan internet dalam kehidupan sehari-hari (Dwijayanti et al., 2021) Penggunaaan internet di Indonesia digunakan sebanyak lebih dari 8 jam perhari menurut survei yang dilakukan APJII tahun 2019-2020, bisa dilihat pada gambar 1 (APJII, 2020).

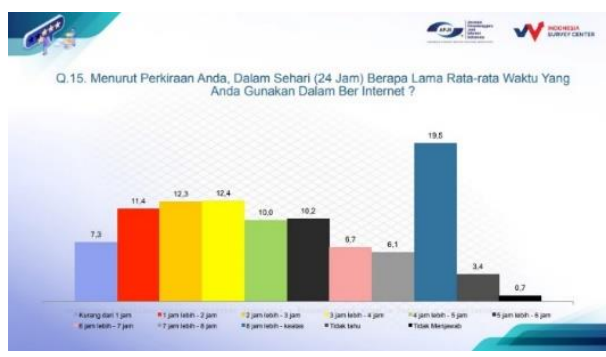

Gambar 1 Durasi Penggunaan Internet di Indonesia Sumber: APJII, 2020

Kegiatan Belajar dari Rumah (BDR) dan Work From Home (WFH) diterapkan pemerintah di DKI Jakarta dan kemudian disusul oleh daerah lainnya. Peningkatan pengunaan teknologi untuk belajar dan bekerja dari rumah tersebut juga pada akhirnya memberikan dampak komunikasi sosial terhadap keluarga maupun masyarakat khususnya di Ibu Kota Jakarta. Penetrasi pengguna internet di Indonesia khususnya pulau Jawa didominasi oleh DKI Jakarta dengan perolehan 80,4\% tahun 2018 mengalami kenaikan sebesar 4,6\% pada tahun 2019 yakni $85,0 \%$ (APJII, 2020), hal yang juga bisa dilihat pada gambar 2.

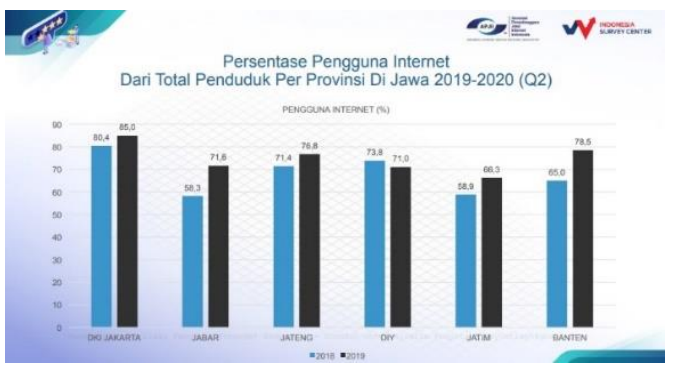

Gambar 2 Persentase Pengguna Internet di Provinsi Jawa Sumber: APJII, 2020

Ketua umum APJII, Jamalul Izza menyatakan bahwa adanya kenaikan jumlah pengguna internet itu dikarenakan oleh beberapa faktor, seperti infrastruktur internet cepat, dan transformasi internet digital semakin masif akibat kebijakan kegiatan Belajar dari Rumah (BDR) serta Work From Home (WFH) karena pandemi Covid19 (APJII, 2020). Keadaan tersebut akhirnya memunculkan perilaku phubbing (phone and snubbing) yang menimbulkan fokus hanya kepada dirinya sendiri dan teknologi smartphone serta mengabaikan seseorang di dalam lingkungannya daripada membangun sebuah percakapan (Prabowo, 2020). Smartphone memang memanjakan para penggunanya untuk terus terhubung dengan jaringan internet dan media sosial tetapi penggunaannya juga mengambil waktu dan perhatian pengguna dari lingkungan sekitar mereka (Suprayitno dan 
Wahyudi, 2020). Phubbing muncul dikarenakan besarnya ketergantungan seseorang pada smartphone dan internet (Hanika, 2015). Dampak dari adanya phubbing menimbulkan gagapnya komunikasi secara langsung dikarenakan sudah terbiasa melakukan komunikasi tidak langsung yakni menggunakan smartphone dan dunia maya (Prabowo, 2020).

Berdasarkan survei yang dilakukan oleh Deka Insight di Jakarta, phubbing banyak dilakukan di lingkungan keluarga sebesar 77\% (Ihsan, 2020). Phubbing dapat mengurangi kuantitas, kualitas dan hubungan secara langsung dengan para anggota keluarga, serta memiliki dampak lain dimana dimana anggota keluarga sebagai lawan bicara merasa tidak dihargai oleh anak atau pun orang tuanya, semakin berkurangnya etika dan sopan santun dalam berinteraksi, lupa waktu belajar dikarenakan terlalu fokus dengan smartphone, lupa waktu makan dan juga melalaikan kewajiban mereka sebagai anggota keluarga dan umat ber-agama (Sirupang et al., 2020)

Adanya perilaku phubbing yang tidak terlepas dari penggunaan smartphone secara terus-menerus setiap harinya dapat berakibat pada merenggangnya hubungan antar anggota keluarga, yang dimana seharusnya anggota keluarga dapat meningkatkan keharmonisan dan kedekatan dengan keluarga (Irawati dan Nurmina, 2020). Hal ini dikarenakan kesibukan mereka memainkan smartphone yang mereka miliki seperti, ketika anak mengerjakan tugas sekolah dan orang tua membantunya namun setiap menit para orang tua melirik smartphone mereka, ketika suami istri sedang makan di restoran smartphone tidak jauh diletakan di sisi mereka untuk dapat mengecek pemberitahuan sesegera mungkin, ketika anak sedang berkumpul diruang televisi keluarga bersama orang tuanya mereka sibuk dengan smartphone masing-masing, tanpa disadari perilaku itu telah mengganggu jalannya komunikasi antar anggota keluarga, yaitu adanya pihak yang merasa diabaikan oleh lawan bicara mereka karena terlalu sibuk dengan smartphone yang dimiliki (Sirupang et al., 2020).

Para anggota keluarga kehilangan kesempatan untuk berkomunikasi dan secara langsung (face to face) dengan pihak yang lain sehingga tidak dapat membangun suatu hubungan yang akrab. Kecenderungan ini mengakibatkan penurunan tingkat keseringan atau frekuensi dan kualitas hubungan tatap muka antar anggota keluarga, diakibatkan oleh masing-masing anggota keluarga itu sendiri baik orang tua atau anak yang hanya fokus dengan smartphone mereka (Sirupang et al., 2020). Interaksi antar anggota keluarga yang minim, dapat mempengaruhi intensitas komunikasi dalam keluarga hingga berdampak buruk pada keharmonisan keluarga itu sendiri (Sirupang et al., 2020).

Berdasarkan uraian diatas, maka peneliti ingin melakukan penelitian berjudul Pengaruh Perilaku Phubbing terhadap Berkurangnya Intensitas Komunikasi Keluarga pada Masa Pandemi Covid-19 di Kota Jakarta.

\section{METODE}

Metode penelitian ini adalah kuantitatif untuk menggambarkan dan kemudian dijelaskan permasalahan yang ada dimana hasilnya dapat digeneralisasikan (Kriyantono, 2014). Paradigma penelitian ini adalah positivistik dimana dalam penelitian ini memiliki asumsi bahwasannya adanya gejala sebab dan akibat yang dikelompokkan kedalam beberapa variabel (Sugiyono, 2014). Penelitian ini memiliki jenis deskriptif yang mana mendeskripsikan secara runtut sesuai dengan fakta dan akurasi mengenai kebenaran terhadap sifat dari populasi suatu objek tertentu (Kriyantono, 2014)

Metode yang digunakan pada penelitian ini ialah metode survei dengan menyebarkan pertanyaan berupa kuesioner kepada responden atau subjek penelitian dengan dibantuan media google forms yang nantinya akan diukur menggunakan Skala Likert sebagai skala pengukuran. Hasil kuesioner menjadi data primer yang didukung oleh data lain yang berasal dari buku dan jurnal. Setiap butir pernyataan item tersebut dihadapkan dengan pilihan jawaban yang mengarah kepada sikap setuju maupun dukungan yang disimbolkan dengan kata-kata: Sangat Setuju (SS); Setuju (S); Tidak Setuju (TS); Sangat Tidak Setuju (STS) (Kriyantono, 2014).

Populasi diartikan sebagai area generalisasi objek atau subjek dimana terdapat berapa jumlah dan kriteria tertentu yang ditetapkan untuk diteliti, dan dijadikan sebuah kesimpulan. Populasi dapat berbentuk orang, organisasi, kata ataupun kalimat, simbol nonverbal, dan lainnya. Populasi juga disebut sebagai unit of analysis atau satuan analisis juga unsur dari pada suatu penelitian (Kriyantono, 2014).

Populasi dalam penelitian ini adalah warga kota Jakarta yang menurut data (Kemkominfo, 2019) melalui Pusat Pelayanan Statiistik Dinas Komunikasi, Informatika, dan Statistik Provinsi DKI Jakarta (2019) berjumlah 10.344.018 juta jiwa.

Sampel merupakan bagian dari sebuah populasi. Purposive sampling digunakan pada penelitian ini sebagai teknil pengambilan sampel karena berdasarkan (Sugiyono, 2014) teknik purposive sampling ialah sebuah teknik penentuan suatu sampel melalui berbagai pertimbangan tertentu. Dikarenakan tidak semua sampel memenuhi kriteria penelitian, maka dari itu digunakanlah purposive sampling dalam penelitian ini agar hasil tepat sasaran dan sesuai dengan kebutuhan dari penelitian itu sendiri. 
Sampel dalam penelitian ini adalah warga di kota Jakarta yang memenuhi kriteria sebagai berikut yaitu: memiliki keluarga, aktif menggunakan smartphone hingga 8 jam perhari (pagi s.d. malam, tinggal di wilayah kota Jakarta, dan pernah menggunakan smartphone ketika sedang berbicara tatap muka dengan lawan bicara.

Untuk mendapatkan sebuah jumlah sampel yang representatif terhadap penelitian, maka peneliti menggunakan rumus slovin karena populasi sudah di ketahui (Sugiyono, 2014). Sampel ditentukan menggunakan Rumus Solvin dengan hasil sebanyak 400 responden.

Dalam hal ini sub-populasi yang dimiliki bersifat heterogen atau tidak sama maka digunakanlah proportional sampling. Dengan teknik proportional sampling ini sampel di hitung berdasarkan perbandingan dengan membagi lagi jumlahnya dengan rumus sebagai berikut:

$$
\frac{\text { Jumlah Sub Populasi }}{\text { Jumlah Populasi Keseluruhan }} x \text { jumlah sampel }
$$

Berdasarkan rumus di atas maka hasil yang didapatkan adalah:

$$
\begin{aligned}
& \text { Kepulauan Seribu }=\frac{27.591}{10.344 .018} \times 400=1,06(\text { pembulatan } 1) \\
& \text { Jakarta Pusat }=\frac{1.138 .516}{10.344 .018} \times 400=44,02(\text { pembulatan } 44) \\
& \text { Jakarta Utara }=\frac{1.715 .581}{10.344 .018} \times 400=66,34(\text { pembulatan } 66) \\
& \text { Jakarta Barat }=\frac{2.326 .721}{10.344 .018} \times 400=89,97(\text { pembulatan } 90) \\
& \text { Jakarta Selatan }=\frac{2.189 .015}{10.344 .018} \times 400=84,64(\text { pembulatan } 85) \\
& \text { Jakarta Timur }=\frac{2.946 .594}{10.344 .018} \times 400=113,94(\text { pembulatan } 114)
\end{aligned}
$$

Anggota keluarga yang tinggal di Kota Jakarta dan penguna aktif smartphone dalam keseharian adalah subjek pada penelitian ini. Sedangkan, perilaku phubbing merupakan objek pada penelitian ini.

Teknik analisis data pada penelitian ini merupakan hasil jawaban dari responden penelitian yang peneliti olah menggunakan statistik dengan aplikasi software SPSS (Statistical Package for Social Sciencer) versi 25 dengan melakukan Uji Validitas, Uji Reliabilitas, Uji Asumsi Klasik yakni Uji Normalitas, Uji Heteroskedastisitas, dan Uji Regresi Linear Sederhana. Sedangkan untuk uji hipotesis, peneliti menggunakan Uji T. Kemudian Uji Koefisien Determinasi dan untuk mengetahui berapa besarnya pengaruh dari variabel tersebut maka digunakanlah Uji Korelasi.

Hipotesis pada penelitian ini adalah:

- Ho: Tidak ada pengaruh perilaku Phubbing terhadap berkurangnya intensitas komunikasi keluarga pada masa pandemi COVID-19 di kota Jakarta

- Ha: Ada pengaruh perilaku Phubbing terhadap berkurangnya intensitas komunikasi keluarga pada masa pandemi COVID-19 di kota Jakarta

\section{HASIL DAN DISKUSI}

\section{Smartphone}

Smartphone dikenal sebagai teknologi telepon pintar dengan fitur kekinian yang memiliki kemampuan setara dengan komputer. Kemampuan ini didasarkan atas penggabungan dari fungsi handpone yang semula hanya dapat melakukan panggilan telepon biasa, kini bergabung dengan fungsional PC dan multimedia. Teknologi yang digunakan pada smartphone mencakup mikroprosesor, memori, dan layar bawaan bersifat modern sehingga dapat digunakan untuk mengirim pesan, video, kamera, game, pemutar musik, search engine, email, tv digital, layanan GPS, hingga internet yang dapat membayar tagihan seperti halnya kartu kredit hanya sekali klik (Williams dan Sawyer, 2015) Fasilitas lainnya didalam smartphone adalah asisten pribadi digital atau disingkat PDA, memiliki layar touchscreen dengan jenis LCD, OLED, dan AMOLED yang kaya akan resolusi warna yang tersebar luas diabad ke-21 dengan kecepatan yang diimilikinya bernama mobile broadband atau istilah yang populer adalah teknologi 4G LTE.

\section{Phubbing}

Phubbing dikenal sebagai sikap mengabaikan seseorang di lingkungan sekitar dengan lebih memilih fokus kepada telepon (smartphone atau gadget) (Chotpitayasunondh dan Douglas, 2018) Ilustrasi mengabaikan dalam phubbing adalah komunikan yang fokus terhadap telepon selulernya sehingga ketika diajak berinteraksi dengan 
lawan bicaranya tidak menunjukkan adanya balasan interaksi secara interpersonal dan lebih memilih untuk melarikan diri (Karadağ et al., 2015).

Uraian diatas menyimpulkan bahwasannya phubbing (Phone and Snubbing) adalah sebuah perilaku atau sikap mengabaikan lawan bicara dalam sebuah percakapan dan lebih memilih untuk fokus pada smartphone dibandingkan berinteraksi atau merespon dan memperhatikan lawan bicara.

Menurut Karadağ et al. (2015) perilaku phubbing disebabkan oleh beberapa faktor yaitu adiksi terhadap smartphone, internet, media sosial dan games yang menyebabkan adanya aspek perilaku dari phubbing antara lain adanya gangguan didalam komunikasinya (communication disturbance) dan obsesi terhadap ponsel (phone obsession). Sementara itu, berdasarkan penelitian oleh (Chotpitayasunondh dan Douglas, 2018) terdapat 4 indikator dari phubbing yaitu sebagai berikut:

1. Nomophobia (no-mobile phone phobia)

2. Interpersonal conflict (konflik interpersonal)

3. Self-isolation (isolasi diri)

4. Problem Acknowledgement (pengakuan masalah)

\section{Komunikasi Keluarga}

Keluarga adalah kelompok utama yang terdiri dua orang atau lebih yang memiliki hubungan interaksi interpersonal secara darah, perkawinan, maupun adopsi yang mana mereka merupakan bagian kecil dari masyarakat yang sudah terlandasi oleh semua institusi yang ada (Kuswanti et al., 2020).

Keluarga kumpulan orang yang hidup bersama dalam satu atap tempat tinggal yang memiliki rasa perutan batin untuk mempengaruhi dan memperhatikan satu sama lain (Fitriana et al., 2020)

Kegiatan komunikasi dalam sebuah keluarga disebut juga sebagai komunikasi keluarga yang mana kegiatan tersebut meliputi interaksi antara anggota keluarga dengan lainnya untuk membentuk dan mengembangkan nilai sebagai pedoman kehidupan dimana pertama kali manusia belajar menjadi makhluk sosial berinteraksi dengan anggota kelompoknya melalui keluargan (Mahmudah et al., 2020).

Dalam komunikasi keluarga, seorang komunikator (penyampai pesan) dapat juga berasal dari orang tua seperti ayah dan ibu kepada anak, kemudian suami dan istri, kakek dan nenek maupun sebaliknya juga dapat sebagai komunikan yang memberi dan menerima pesan. Jenis pesan yang disampaikan dalam komunikasi keluarga yakni berupa informasi, anjuran berupa nasihat-nasihat, arah petunjuk, maupun bantuan yang mana melibatkan orang sebanyak dua paling sedikit, dengan sifat dan nilai, tingkah laku, khas yang tentu memiliki perbedaan antara satu dengan lainnya (Kaddi et al., 2020).

Banyak peran dalam sebuah keluarga yang dapat dijalankan dan dibangun dalam sebuah keluarga salah satunya adalah tukar pikiran dengan saling berdialog dan melakukan negosiasi dengan anggota keluarga (Kuswanti et al., 2020). Hal ini dilakukan untuk dapat memunculkan dampak baik bagi kestabilan sistem keluarga dimana fungsi ini untuk meningkatkan hubungan antar manusia atau human relation, menghindari konflik dan pergolakan interpersonal dalam keluarga, mengurangi ketidakpastian dan membagikan pengetahuan serta pengalaman (Kuswanti et al., 2020).

\section{Komunikasi Keluarga dan Penggunaan Media Komunikasi}

Teknologi adalah bagian dari lingkungan keluarga, dan adopsi teknologi baru mempengaruhi sistem keluarga. Kecanggihan teknologi mengubah cara keluarga berkomunikasi dan memiliki dampak signifikan pada kebersamaan keluarga (Bacigalupe dan Bräuninger, 2017).

Media dan teknologi menjadi alat komunikasi yang dapat digunakan anggota keluarga secara positif (misalnya untuk membuat hubungan penting satu sama lain, atau untuk mendukung satu sama lain di saat krisis) atau secara negatif (misalnya untuk menyerang privasi satu sama lain) (Turner dan West, 2018) Media menjadi sarana penghubung dalam keluarga, dimana dapat membantu anggota keluarga yang terpisah secara geografis atau berjauhan untuk terhubung satu sama lain (Turner dan West, 2018)

Di satu sisi keberadaan teknologi smartphone adalah jalan keluar dari masalah keterbatasan jarak dan waktu yang dimiliki orang tua dan anak untuk berkomunikasi. Tapi, anak yang menggunakan smartphone dan tidak dibatasi dan dikontrol oleh orang tuanya juga dapat mengurangi intensitas komunikasi secara langsung antara orang tua dan anak di rumah. Sehingga penggunaan smartphone dalam keluarga dapat mengurangi keefektifan komunikasi dalam keluarga itu sendiri yang dapat diukur dari segi intensitas, komunikasi dua arah, sikap mendengarkan lawan bicara, hingga perhatian dan empati dalam sebuah percakapan (Prabandari dan Rahmiaji, 2019). 


\section{Intensitas Komunikasi Keluarga}

Intensitas komunikasi digunakan untuk mengukur kedalaman komunikasi dengan melihat siapa dan apa yang menjadi pembicaraan, pikiran, perasaan dan objek tertentu baik orang lain atau diri sendiri. Hal ini sangat penting untuk menimbulkan rasa keeratan dan kesatuan hubungan antar keluarga, serta memberi rasa aman. (Munawaroh dan Azizah, 2018)

Menurut (Devito, 2011) bahwa intensitas komunikasi keluarga terdapat 6 indikator diantaranya, yaitu:

1. Frekuensi Berkomunikasi

Tingkat keseringan atau banyaknya komunikasi yang terjadi dalam sebuah keluarga, seperti halnya dilakukan setiap hari, seminggu 4-5 hari lain sebagainya.

2. Durasi yang Digunakan untuk Berkomunikasi

Seberapa lama rentang waktu yang digunakan dalam melaksanakan aktivitas komunikasi. Durasi ini beragam dan bervariasi. Sebagai contoh, saat waktu pertama kali bertemu dapat menghabiskan waktu 23 jam maupun dapat berkurang atau lebih

3. Perhatian yang Diberikan saat Berkomunikasi

Fokus dan memperhatikan dengan seksama apa yang diutarakan oleh partisipan saat berkomunikasi yang merujuk pada aktivitas penyampaian pesan dari anak ke orang tua atau orang tua kepada anak.

4. Keteraturan dalam Berkomunikasi

Adanya persamaan jumlah keadaan, kegiatan maupun proses yang dilakukan berulang kali secara rutin saat melaksanakan aktivitas komunikasi.

5. Tingkat Keluasan Pesan Komunikasi \& Jumlah Orang yang Diajak Berkomunikasi

Adanya jangkauan dan variasi topik pembicaraan yang dilakukan saat melakukan aktivitas komunikasi serta jumlah orang saat berkomunikasi, seluruh anggota atau hanya sebagian.

6. Tingkat Kedalaman Komunikasi

Pesan yang disampaikan memiliki makna mendalam dan detail dengan ditandai adanya kejujuran, keterbukaan, dan kepercayaan pada saat berkomunikasi dengan lawan bicara.

\section{Determinisme Teknologi}

Teori ini diperkenalkan pertama kali oleh Marshall McLuhan pada tahun 1962 dalam karya tulisnya berjudul "The Guttenberg Galaxy: The Making of Typographic Man". Inti dari teori ini ialah bahwasannya perubahan akan membentuk keberadaan manusia dalam berkomunikasi (McLuhan, 2003) yang artinya bahwa perubahan itu datang dari interaksi sosial bermasyarakat yang ditentukan dari adanya teknologi yang menjadi makanan seharihari oleh masyarakatnya (McLuhan, 2003)

Teknologi memiliki pengaruh untuk menentukan kemajuan dan perilaku dalam masyarakat sebagai determinisme teknologi. Menurut Val Dusek, determinisme teknologi adalah tuntutan bahwa teknologi dapat membuktikan kehidupan masyarakat dan budayanya (Mulyadi, 2020). Marshall McLuhan menganggap bahwa teknologi membatasi praktik sosial manusia di satu sisi, namun pada sisi lainnya media teknologi dapat membukan panorama keterbatasan yang memungkinkan manusia meningkatkan capaian dan memperluas jangkauan mereka (McLuhan, 2003)

McLuhan beranggapan bahwasannya medialah yang menjadi faktor utama untuk mempengaruhi hal lainnya. Secara Umum, dalam teori determinsime teknologi yang diperkenalkan oleh McLuhan menerangkan bahwasannya media merupakan sarana atau alat yang membentuk pola pikir masyarakat untuk merasakan dan melakukan sebuah tindakan tertentu (Nurudin, 2017).

Pemikiran dari teori ini antara lain, 1). Adanya penemuan baru atau inovasi dibidang teknologi memberikan dampak perubahan pada budaya, 2). Cara komunikasi yang berubah dan membentuk keeksistensian kehidupan manusia, dan 3). McLuhan menyatakan bahwa "We shape our tools, and they in turn shape us" (kitalah yang membentuk sebuah alat yang kita perlukan dan sekarang alat itulah yang membentuk diri kita) (Nurudin, 2017).

Determinisme teknologi meyakini bahwasannya adanya penemuan teknologi dan perkembangannya merupakan salah satu faktor mengubah kebudayaan manusia. Teknologi itu membentuk bagaimana pola pikir, tingkah laku masyarakat yang berjalan dari era satu ke era lainnya dalam kehidupan manusia (McLuhan, 2003)

McLuhan menyatakan bahwa di samping manfaat teknologi, terdapat dampak negatif terhadap kehidupan manusia. Di satu sisi, teknologi memberikan kemudahan dalam meningkatkan capaian dan memperluas jangkauan keterbatasan kemampuan manusia. Di sisi lain, penggunaan teknologi memungkinkan manusia teramputasi dari tugas dan fungsinya, baik secara fisik maupun mental yang menyebabkan hilangnya harkat (dehumanisasi) sebagai makhluk sosial (McLuhan, 2003) 


\section{Uji Validitas dan Reliabilitas}

Kuesioner disebar pada 30 responden awal yang kemudian hasil datanya di uji menggunakan uji validitas Pearson Product Moment. Berdasarkan hasil uji validitas yang telah dilakukan peneliti, seluruh pernyataan yang berjumlah 28 item dinyatakan pernyataan valid karena rhitung > rtabel 0,361.

Sebuah penelitian yang baik wajib menggunakan indeks atau alat ukur yang dapat diandalkan dan dipercaya. Menurut Sugiyono (2014) menentukan suatu instrumen penelitian dapat dipakai lebih dari satu kali dan tetap menghasilkan data yang konsisten maka uji reliabilitas ini diperlukan. Sebuah kuesioner penelitian dinyatakan reliable jika nilai Cronbach's Alpha > 0,6 (Sujarweni, 2014). Hasil uji reliabilitas dari 28 pernyataan dalam penelitian ini dinyatakan reliabel karena kedua variabel memiliki nilai lebih besar dari Cronbach's Alpha 0,6 . Dimana hasil uji reliabilitas variabel $X$ mendapatkan nilai sebesar $0,896>0,6$ dan hasil uji reliabilitas variabel Y mendapatkan nilai sebesar $0,850>0,6$. Berikut adalah tabel Interpretasi reliabilitas:

Tabel 1 Interpretasi Reliabilitas

\begin{tabular}{cc}
\hline Nilai Koefisien & Tingkat Hubungan \\
\hline $0,00-0,199$ & Reliabilitas Sangat Rendah \\
$0,20-0,399$ & Reliabilitas Rendah \\
$0,40-0,599$ & Reliabilitas Sedang \\
$0,60-0,799$ & Reliabilitas Tinggi \\
$0,80-1,000$ & Reliabilitas Sangat Tinggi \\
\hline
\end{tabular}

Sumber: Kriyantono, 2014

Berdasarkan tabel 1 Interpretasi reliabilitas nilai dari Cronbach's Alpha variabel X perilaku phubbing dan variabel $\mathrm{Y}$ intensitas komunikasi keluarga masuk dalam kategori tingkat hubungan reliabilitas sangat tinggi.

\section{Analisis Data Responden}

Untuk mengetahui pengaruh perilaku phubbing terhadap intensitas komunikasi keluarga pada masa pandemi Covid-19 di kota Jakarta, peneliti telah melakukan pengumpulan data pada anggota keluarga yang tinggal di wilayah Jakarta dengan cara menyebarkan kuesioner melalui link google forms kepada sampel penelitian sebanyak 400 responden dari total populasi penelitian yang berjumlah 10.344 .018 orang.

\section{Responden Berdasarkan Jenis Kelamin}

Berdasarkan tabel 2 dan gambar 3 diketahui dari 400 kuesioner yang disebar, responden berjenis kelamin perempuan adalah responden yang mendominasi hasil penelitian, yakni sebanyak 277 orang dengan nilai persentase 69\%. Sementara responden lainnya berjenis kelamin laki-laki sejumlah 123 orang dengan nilai persentase $31 \%$.

Berdasarkan tabel 3, terlihat bahwa responden pada rentang usia 15 - 24 tahun sebanyak 360 orang dengan presentase sebesar 90\%, responden yang berusia 25 - 34 tahun tsebanyak 12 orang dengan presentase sebesar 3\%, responden yang berusia 35-44 tahun sebanyak 14 orang dengan presentase sebesar $3,5 \%$, kemudian responden yang berusia $45-54$ tahun sebanyak 13 orang dengan presentase sebesar 3,25\%, dan responden yang berusia 59 tahun sebanyak 1 orang dengan presentase sebesar $0,25 \%$. 
Berikut data responden berdasarkan jenis kelamin:

Tabel 1 Responden Berdasarkan Jenis Kelamin

\begin{tabular}{ccc}
\hline Jenis Kelamin & Frekuensi & Persentase (\%) \\
\hline Laki-Laki & 123 & 31 \\
Perempuan & 277 & 69 \\
\hline Jumlah & 400 & 100
\end{tabular}

Sumber: Data kuesioner yang diolah peneliti (2021)

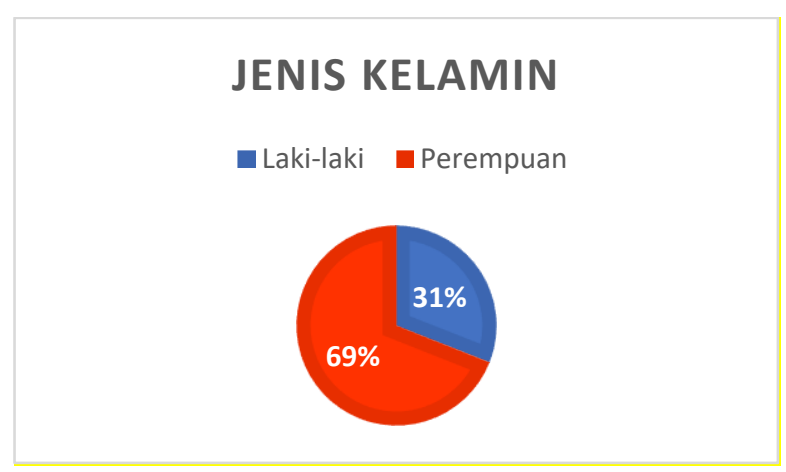

Gambar 3 Jenis Kelamin

\section{Responden Berdasarkan Usia}

Tabel 2 Responden Berdasarkan Usia

\begin{tabular}{ccc}
\hline Usia & Frekuensi & Persentase (\%) \\
\hline $15-24$ & 360 & 90 \\
$25-34$ & 12 & 3 \\
$35-44$ & 14 & 3,5 \\
$45-54$ & 13 & 3,25 \\
59 & 1 & 0,25 \\
\hline Jumlah & 400 & 100
\end{tabular}

Sumber: Data kuesioner yang diolah peneliti (2021)

\section{Responden Berdasarkan Pekerjaan}

Berdasarkan tabel 4, terlihat bahwa responden dengan pekerjaan sebagai pelajar/mahasiswa sebanyak 324 orang dan memiliki presentase sebesar $81 \%$, responden penelitian dengan pekerjaan sebagai karyawan swasta sebanyak 37 orang dan memiliki presentase sebesar $9,25 \%$, responden dengan pekerjaan sebagai guru sebanyak 13 orang dan memiliki presentase sebesar 3,25\%, responden dengan pekerjaan PNS (Pegawai Negeri Sipil) sebanyak 2 orang dan memiliki presentase sebesar $0,5 \%$, responden dengan pekerjaan sebagai wirausaha sebanyak 5 orang dan memiliki presentase sebesar 1,25\%, kemudian responden dengan pekerjaan sebagai freelancer sebanyak 9 orang dan memiliki presentase sebesar 2,25\%, lalu responden penelitian dengan pekerjaan sebagai Ibu Rumah Tangga sebanyak 10 orang dan memiliki presentase sebesar 2,5\%. 
Tabel 3 Responden Berdasarkan Pekerjaan

\begin{tabular}{ccc}
\hline Pekerjaan & Frekuensi & Persentase (\%) \\
\hline Pelajar/Mahasiswa & 324 & 81 \\
Karyawan Swasta & 37 & 9,25 \\
Guru & 13 & 3,25 \\
PNS & 2 & 0,5 \\
Wirausaha & 5 & 1,25 \\
Freelancer & 9 & 2,25 \\
Ibu Rumah Tangga & 10 & 2,5 \\
\hline Jumlah & 400 & 100 \\
Sumber: Data kuesioner yang diolah peneliti (2021)
\end{tabular}

\section{Responden Berdasarkan Peran dalam Keluarga}

Berdasarkan tabel 5, terlihat bahwa responden yang berperan sebagai Ayah sebanyak 10 orang dan memiliki presentase sebesar 2,5\%, responden yang berperan sebagai Ibu sebanyak 21 orang dan memiliki presentase sebesar 5,2\%, responden yang berperan sebagai Kakak (anak pertama) sebanyak 158 orang dan memiliki presentase sebesar 39,5\%, lalu responden yang berperan sebagai Adik (anak kedua, ketiga, dst) sebanyak 211 orang dan memiliki presentase sebesar $52,8 \%$.

Tabel 4 Responden Berdasarkan Peran dalam Keluarga

\begin{tabular}{ccc}
\hline Peran Keluarga & Frekuensi & Persentase (\%) \\
\hline Ayah & 10 & 2,5 \\
Ibu & 21 & 5,2 \\
Kakak (Anak & 39,5 \\
$\begin{array}{c}\text { Pertama) } \\
\text { Adik (Anak } \\
\text { kedua, ketiga, } \\
\text { dst) }\end{array}$ & 158 & 52,8 \\
\hline $\begin{array}{c}\text { Jumlah } \\
\text { dum }\end{array}$ & 211 & 100
\end{tabular}

Sumber: Data kuesioner yang diolah peneliti (2021)

Uji normalitas berguna untuk mengetahui apakah dalam model regresi, variabel dependen dan variabel independen memiliki distribusi normal atau tidak. Uji normalitas yang peneliti gunakan dalam penelitian ini dengan menggunakan Uji Kolmogorov-Smirnov (KS Test). Hasil uji asumsi klasik menunjukkan pada uji Kolmogorov-Smirnov Test nilai Asymp. Sig $0.156>0,05$ dan nilai Monte Carlo sebesar 0,579 > 0,05 maka model regresi memenuhi asumsi normalitas dan data dinyatakan berdistribusi normal.

Berdasarkan hasil pengujian uji heteroskedastisitas Glejser didapat bahwa nilai variabel independen tidak terjadi heteroskedastisitas. Dimana dalam tabel nilai signifikasi variabel X Perilaku Phubbing bernilai $0,134>0,05$. Sehingga disimpulkan bahwasanya tidak terjadi masalah heteroskedastisitas pada model regresi. 


\section{Perilaku Phubbing}

Phubbing (phone and snubbing) adalah perilaku atau sebuah sikap mengabaikan lawan bicara dalam sebuah percakapan dan lebih memilih untuk fokus kepada smartphone dibandingkan berinteraksi dan memperhatikan lawan bicara. Indikator Perilaku phubbing menurut (Chotpitayasunondh dan Douglas, 2018) adalah: (1) nomophobia (no-mobile phone phobia), (2) interpersonal conflict (konflik interpersonal dengan lawan bicara), (3) self-Isolation (isolasi diri dari percakapan), dan (4) problem acknowledgement (pengakuan masalah yang telah dilakukan selama percakapan berlangsung).

Pada penelitian ini kuesioner disebar kepada seluruh masyarakat yang tinggal di wilayah DKI Jakarta. Data yang didapat dari responden kemudian dianalisis berdasarkan perhitungan frekuensi dan persentase. Untuk menetapkan kategori seberapa besar skala dari variabel penelitian maka dapat diukur dengan perbandingan skor aktual dan skor ideal. Berikut ini adalah nilai rata-rata jawaban yang dapat dikategorikan untuk rentang kategori skala dengan skor minimum sama dengan 1 , skor maksimum sama dengan 4 dan lebar skala sama dengan $(4-1) / 4=0,75$.

Tabel 5 Kategori Skala

\begin{tabular}{cc}
\hline Skala & Keterangan \\
\hline $1,00-1,75$ & Sangat Rendah \\
$1,76-2,51$ & Rendah \\
$2,54-3,27$ & Tinggi \\
$3,28-4,00$ & Sangat Tinggi \\
\hline
\end{tabular}

Sumber: Sugiyono, 2014

\section{Nomophobia (no-mobile phone phobia)}

Nomophobia (no-mobile phone phobia) dapat di artikan sebagai ketakutan berlebih seseorang ketika smartphone atau gadget tidak ada di dekatnya sehingga menimbukan sebuah rasa ketergantungan dan juga kekhawatiran yang berlebih jika tidak menggunakan smartphone. Dari total 400 responden, menghasilkan nilai rata-rata sebesar 2,92 dan masuk ke dalam kategori skala tinggi. Hal ini berarti bahwa responden penelitian mengalami nomophobia (no mobile phone phobia) dimana mereka tidak bisa melepaskan smartphone dari genggaman selama masa pandemi Covid-19.

\section{Interpersonal Conflict (Konflik Interpersonal)}

Interpersonal Conflict adalah konflik interpersonal yang terjadi di dalam sebuah hubungan antar dua orang atau lebih. Dalam penelitian ini adalah antar anggota keluarga. Dari total 400 responden, menghasilkan nilai rata-rata sebesar 3,23. Hal ini berarti bahwa responden penelitian memiliki konflik interpersonal dengan anggota keluarganya yang disebabkan oleh penggunaan teknologi smartphone secara terus menerus sehingga anggota keluarga mengeluhkan hal tersebut.

\section{Self Isolation (Isolasi Diri)}

Self Isolation adalah individu yang mengisolasi diri atau menjauhkan diri dari sebuah percakapan dan lebih berfokus pada smartphone dibandingkan lawan bicara. Dari total 400 responden, menghasilkan nilai rata-rata sebesar 3,49 dan masuk ke dalam kategori skala sangat tinggi. Hal ini berarti bahwa responden penelitian lebih merasa puas ketika mereka mengabaikan lawan bicara dan berfokus pada smartphone. 
Tabel 6 Tabulasi Data Perilaku Phubbing

\begin{tabular}{|c|c|c|c|c|c|c|c|c|c|c|c|}
\hline \multirow{2}{*}{$\begin{array}{l}\text { Indikator } \\
\text { Variabel X }\end{array}$} & \multirow{2}{*}{ No. } & \multicolumn{4}{|c|}{ Frekuensi Jawaban } & \multirow{2}{*}{$\begin{array}{l}N= \\
400\end{array}$} & \multirow{2}{*}{$\begin{array}{l}\text { Jumlah } \\
\text { Skor }\end{array}$} & \multirow{2}{*}{ Mean } & \multirow{2}{*}{$\begin{array}{l}\text { Total } \\
\text { Mean }\end{array}$} & \multirow{2}{*}{$\begin{array}{l}\text { Nilai } \\
\text { Rata- } \\
\text { Rata }\end{array}$} & \multirow{2}{*}{ Ket } \\
\hline & & SS & $\mathbf{S}$ & TS & STS & & & & & & \\
\hline \multirow{4}{*}{$\begin{array}{c}\text { Nomophobia } \\
\text { (No Mobile Phone } \\
\text { Phobia) }\end{array}$} & $\mathrm{P} 1$ & 148 & 118 & 103 & 31 & 400 & 1,183 & 2.96 & \multirow{4}{*}{2.92} & \multirow{14}{*}{3.30} & \multirow{14}{*}{$\begin{array}{l}\text { Sangat } \\
\text { Tinggi }\end{array}$} \\
\hline & $\mathrm{P} 2$ & 95 & 107 & 146 & 52 & 400 & 1,045 & 2.61 & & & \\
\hline & P3 & 246 & 87 & 52 & 15 & 400 & 1,364 & 3.41 & & & \\
\hline & P4 & 90 & 130 & 145 & 35 & 400 & 1,075 & 2.69 & & & \\
\hline \multirow{5}{*}{$\begin{array}{c}\text { Interpersonal } \\
\text { conflict } \\
\text { (Konflik } \\
\text { Interpersonal) }\end{array}$} & P5 & 135 & 112 & 124 & 29 & 400 & 1,153 & 2.88 & \multirow{5}{*}{3.23} & & \\
\hline & P6 & 79 & 125 & 150 & 46 & 400 & 1,037 & 2.59 & & & \\
\hline & P7 & 292 & 46 & 53 & 9 & 400 & 1,421 & 3.55 & & & \\
\hline & P8 & 286 & 54 & 50 & 10 & 400 & 1,416 & 3.54 & & & \\
\hline & P9 & 298 & 41 & 55 & 6 & 400 & 1,431 & 3.58 & & & \\
\hline \multirow{3}{*}{$\begin{array}{c}\text { Self-isolation } \\
\text { (Isolasi Diri) }\end{array}$} & P10 & 242 & 97 & 51 & 10 & 400 & 1,371 & 3.43 & \multirow{3}{*}{3.49} & & \\
\hline & P11 & 269 & 79 & 45 & 7 & 400 & 1,410 & 3.53 & & & \\
\hline & P12 & 269 & 79 & 44 & 8 & 400 & 1,409 & 3.52 & & & \\
\hline \multirow{2}{*}{$\begin{array}{c}\text { Problem } \\
\text { Acknowledgement } \\
\text { (Pengakuan } \\
\text { Masalah) }\end{array}$} & P13 & 230 & 122 & 39 & 9 & 400 & 1,373 & 3.43 & \multirow{2}{*}{3.57} & & \\
\hline & P14 & 318 & 52 & 23 & 7 & 400 & 1,481 & 3.70 & & & \\
\hline
\end{tabular}

Sumber: Data kuesioner yang diolah peneliti (2021)

\section{Problem Acknowledgement (Pengakuan Masalah)}

Problem acknowledgement adalah secara sadar mengetahui adanya akibat yang ditimbulkan karena penggunaan smartphone. Dari total 400 responden, menghasilkan nilai rata-rata sebesar 3,57 dan masuk ke dalam kategori skala sangat tinggi. Hal ini berarti bahwa responden mengetahui akan adanya masalah dengan anggota keluarga seperti tahu bahwa akan kehilangan kesempatan untuk berbicara dengan anggota keluarga karena terlalu fokus menggunakan smartphone, juga sering menunda beberapa aktivitas karena terlalu asyik menggunakan smartphone selama pandemi Covid-19.

Pada tabel 7 tabulasi data menunjukkan bahwa seluruh jawaban dari responden penelitian terhadap variabel $X$ yakni perilaku phubbing masuk kedalam kategori skala sangat tinggi, dimana tabulasi data menghasilkan nilai rata-rata sebesar 3,30 dan berada pada rentang skor nterval 3,28-4,00 yang artinya masuk kedalam kategori penilaian sangat tinggi. Rata-rata skor tertinggi yang mempengaruhi perilaku phubbing dimiliki oleh pernyataan nomor 14 "saya menunda beberapa aktivitas ketika saya menggunakan smartphone selama pandemi Covid-19" sebesar 3,70 untuk indikator Problem Acknowledgement (Pengakuan Masalah) dan skor rata-rata terendah dimiliki oleh pernyataan nomor 6 "Saya merasa kesal jika anggota keluarga saya meminta saya untuk mematikan smartphone saat berbicara dengan mereka" untuk indikator Interpersonal Conflict (Konflik Interpersonal) sebesar 2,59. 


\section{Intensitas Komunikasi Keluarga}

Intensitas komunikasi keluarga adalah sebuah ukuran untuk menggambarkan seberapa sering komunikasi antar anggota keluarga terjadi dalam keseharian. Menurut (Devito, 2011), bahwa intensitas komunikasi keluarga dapat diukur dengan 6 indikator sebagai berikut: (1) Frekuensi Komunikasi, (2) Durasi Komunikasi, (3) Perhatian yang Diberikan Saat Berkomunikasi, (4) Keteraturan Komunikasi, (5) Tingkat Keluasan Pesan \& Jumlah Orang yang Diajak Berkomunikasi, dan (6) Tingkat Kedalaman Komunikasi. Kemudian, indikator dari variabel tersebut dikembangkan oleh peneliti menjadi 14 pernyataan. Berikut merupakan hasil kuesioner penelitian disertai dengan penjabarannya:

\section{Frekuensi Komunikasi}

Tingkat keseringan atau banyaknya proses komunikasi terjadi di dalam sebuah keluarga, antara anak dan orang tua ataupun sebaliknya. Pada kuesioner ini peneliti membagi waktunya menjadi Sangat Sering (berkomunikasi dengan anggota keluarga setiap hari), Sering (berkomunikasi dengan anggota keluarga $4-5$ hari dalam seminggu), Jarang (berkomunikasi dengan anggota keluarga $2-3$ hari dalam seminggu, dan Sangat Jarang (berkomunikasi dengan anggota keluarga 1 hari dalam seminggu). Kemudian, responden penelitian merasa waktu mengobrol dengan keluarga berkurang karena mereka sibuk dengan smartphonenya masing-masing selama pandemi Covid-19. Dari total 400 responden menghasilkan nilai ratarata sebesar 3,14 dan masuk ke dalam kategori skala tinggi.

\section{Durasi Komunikasi}

Rentang waktu atau lama durasi yang digunakan dalam aktivitas komunikasi. Durasi ini beragam dan bervariasi, peneliti membaginya menjadi Sangat Lama (lebih dari 3 jam dalam sehari), Lama (2 - 3 jam dalam sehari), Cepat (1 jam dalam sehari) dan Sangat Cepat (30 menit dalam sehari) selama pandemi Covid-19. Dari total 400 responden menghasilkan nilai rata-rata sebesar 3,05 dan masuk ke dalam kategori skala tinggi.

\section{Perhatian yang Diberikan Saat Berkomunikasi}

Fokus dan memperhatikan dengan seksama apa yang diutarakan oleh partisipan saat berkomunikasi yang merujuk pada aktivitas penyampaian pesan dari anak ke orang tua atau orang tua kepada anak. Dari total 400 responden menghasilkan nilai rata-rata sebesar 3,25 dan masuk ke dalam kategori skala tinggi. Hal ini menunjukkan bahwa responden penelitian tetap fokus memperhatikan anggota keluarga mereka ketika mengobrol selama pandemi Covid-19.

\section{Keteraturan Komunikasi}

Adanya persamaan jumlah keadaan, kegiatan maupun proses yang dilakukan berulang kali secara rutin saat melaksanakan aktivitas komunikasi. Anak dan orang tua mengobrol sebelum tidur atau setelah makan malam mengenai aktivitas yang mereka lakukan dalam waktu satu hari. Dari total 400 responden menghasilkan nilai rata-rata sebesar 3,04 dan masuk ke dalam kategori skala tinggi.

\section{Tingkat Keluasan Pesan \& Jumlah Orang yang Diajak Berkomunikasi}

Adanya jangkauan dan variasi topik pembicaraan yang dilakukan saat melakukan aktivitas komunikasi serta jumlah orang saat berkomunikasi, apakah seluruh anggota keluarga atau hanya sebagian saja. Dari total 400 responden menghasilkan nilai rata-rata sebesar 2,88 dan masuk ke dalam kategori skala tinggi.

\section{Tingkat Kedalaman Komunikasi}

Pesan yang disampaikan memiliki makna mendalam dan detail dengan ditandai adanya kejujuran, keterbukaan, dan kepercayaan pada saat berkomunikasi dengan lawan bicara. Dari total 400 responden menghasilkan nilai rata-rata sebesar 3,32 dan masuk ke dalam kategori skala tinggi. 
Tabel 7 Tabulasi Data Intensitas Komunikasi Keluarga

\begin{tabular}{|c|c|c|c|c|c|c|c|c|c|c|c|}
\hline \multirow{2}{*}{$\begin{array}{l}\text { Indikator } \\
\text { Variabel Y }\end{array}$} & \multirow{2}{*}{ No. } & \multicolumn{4}{|c|}{ Frekuensi Jawaban } & \multirow{2}{*}{$\begin{array}{l}N= \\
400\end{array}$} & \multirow{2}{*}{$\begin{array}{l}\text { Jumlah } \\
\text { Skor }\end{array}$} & \multirow{2}{*}{ Mean } & \multirow{2}{*}{$\begin{array}{l}\text { Total } \\
\text { Mean }\end{array}$} & \multirow{2}{*}{$\begin{array}{l}\text { Nilai } \\
\text { Rata- } \\
\text { rata }\end{array}$} & \multirow{2}{*}{ Ket } \\
\hline & & SS & $\mathbf{S}$ & TS & STS & & & & & & \\
\hline \multirow{2}{*}{$\begin{array}{l}\text { Frekuensi } \\
\text { Komunikasi }\end{array}$} & P1 & 292 & 69 & 32 & 7 & 400 & 1,446 & 3.62 & \multirow{2}{*}{3.14} & & \\
\hline & P2 & 98 & 123 & 127 & 52 & 400 & 1,067 & 2.67 & & & \\
\hline $\begin{array}{c}\text { Durasi } \\
\text { Komunikasi }\end{array}$ & P3 & 156 & 144 & 64 & 36 & 400 & 1,220 & 3.05 & 3.05 & & \\
\hline \multirow{2}{*}{$\begin{array}{l}\text { Perhatian yang } \\
\text { Diberikan Saat } \\
\text { Berkomunikasi }\end{array}$} & P4 & 163 & 166 & 60 & 11 & 400 & 1,281 & 3.20 & \multirow{2}{*}{3.25} & & \\
\hline & P5 & 179 & 168 & 43 & 10 & 400 & 1,316 & 3.29 & & & \\
\hline \multirow{3}{*}{$\begin{array}{l}\text { Keteraturan } \\
\text { Komunikasi }\end{array}$} & P6 & 122 & 150 & 105 & 23 & 400 & 1,171 & 2.93 & \multirow{3}{*}{3.04} & & \\
\hline & P7 & 142 & 172 & 67 & 19 & 400 & 1,237 & 3.09 & & 3.11 & Tinggi \\
\hline & P8 & 143 & 171 & 71 & 15 & 400 & 1,242 & 3.11 & & & \\
\hline \multirow{4}{*}{$\begin{array}{l}\text { Tingkat } \\
\text { Keluasan Pesan } \\
\text { \& Jumlah Orang } \\
\text { yang Diajak } \\
\text { Berkomunikasi }\end{array}$} & P9 & 138 & 191 & 57 & 14 & 400 & 1,253 & 3.13 & \multirow{4}{*}{2.88} & & \\
\hline & P10 & 81 & 115 & 150 & 54 & 400 & 1,023 & 2.56 & & & \\
\hline & P11 & 96 & 165 & 115 & 24 & 400 & 1,133 & 2.83 & & & \\
\hline & P12 & 110 & 203 & 67 & 20 & 400 & 1,203 & 3.01 & & & \\
\hline \multirow{2}{*}{$\begin{array}{l}\text { Tingkat } \\
\text { Kedalaman } \\
\text { Komunikasi }\end{array}$} & P13 & 172 & 159 & 56 & 14 & 400 & 1,291 & 3.23 & \multirow{2}{*}{3.32} & & \\
\hline & P14 & 202 & 166 & 23 & 9 & 400 & 1,361 & 3.40 & & & \\
\hline
\end{tabular}

Sumber: Data kuesioner yang diolah peneliti (2021)

Pada tabel 8 tabulasi data menunjukkan bahwa seluruh jawaban dari responden penelitian terhadap variabel $Y$ yakni intensitas komunikasi keluarga masuk kedalam kategori skala tinggi, dimana tabulasi data menghasilkan nilai rata-rata sebesar 3,11 dan berada pada rentang skor nterval 2,52 - 3,27 yang artinya masuk kedalam kategori penilaian sangat tinggi. Rata-rata skor tertinggi yang mempengaruhi Intensitas Komunikasi Keluarga dimiliki oleh pernyataan nomor 1 "saya berkomunikasi dengan anggota keluarga setiap hari selama masa pandemi Covid-19" untuk indikator Frekuensi Komunikasi sebesar 3,62 dan skor rata-rata terendah dimiliki oleh pernyataan nomor 10 "Saya membicarakan hal-hal berat seperti politik dan ekonomi dengan keluarga selama pandemi Covid-19" untuk indikator Tingkat Keluasan Pesan \& Jumlah Orang yang Diajak Berkomunikasi sebesar 2,56. 


\section{Hasil Uji Hipotesis}

Tabel 8 Uji Hipotesis X Terhadap Y

\begin{tabular}{|c|c|c|c|c|c|}
\hline \multirow[b]{3}{*}{ Model } & \multicolumn{3}{|c|}{ Coefficients } & \multirow[b]{3}{*}{$\mathrm{t}$} & \multirow[b]{3}{*}{ Sig. } \\
\hline & \multicolumn{2}{|c|}{$\begin{array}{l}\text { Unstandardize } \\
\text { d Coefficients }\end{array}$} & $\begin{array}{c}\text { Standardized } \\
\text { Coefficients }\end{array}$ & & \\
\hline & $\mathrm{B}$ & $\begin{array}{l}\text { Std. } \\
\text { Error }\end{array}$ & Beta & & \\
\hline 1 (Constant) & 12.531 & 1.616 & & 7.756 & .000 \\
\hline Perilaku & .670 & .035 & .691 & 19.05 & .000 \\
\hline Phubbing & & & & 3 & \\
\hline
\end{tabular}

a. Dependent Variable: Intensitas Komunikasi Keluarga

Sumber: Data kuesioner yang diolah peneliti (2021)

Kemudian, hasil uji hipotesis menyatakan bahwa nilai sig. pada variabel Perilaku Phubbing sebesar 0,000 $<$ 0,005 dan thitung 19,053 > ttabel 1,984 sehingga Ho ditolak dan Ha diterima. Hal ini menunjukkan bahwa variabel $X$ yaitu Perilaku Phubbing secara parsial berpengaruh terhadap variabel $Y$ berkurangnya Intensitas Komunikasi Keluarga pada Masa Pandemi Covid-19 di Kota Jakarta.

Table 10 Model Summary

Model Summary

\begin{tabular}{lcccc}
\multicolumn{5}{c}{ Model Summary } \\
\hline Model & $\mathrm{R}$ & Square & $\begin{array}{c}\text { Adjusted } \mathrm{R} \\
\text { Square }\end{array}$ & $\begin{array}{c}\text { Std. Error of } \\
\text { the Estimate }\end{array}$ \\
\hline 1 & $.691^{\mathrm{a}}$ & .477 & .476 & 4.821 \\
\hline a. Predictors: (Constant), Perilaku Phubbing & \\
\multicolumn{3}{c}{ Sumber: Data kuesioner yang diolah peneliti (2021) }
\end{tabular}

Berdasarkan hasil uji koefisien determinasi (R2) diperoleh nilai R Square sebesar 0,477 yang artinya variabel X Perilaku Phubbing memberikan pengaruh sebesar 47,7\% terhadap Berkurangnya Intensitas Komunikasi Keluarga pada Masa Pandemi Covid-19 di Kota Jakarta. Sisanya dipengaruhi faktor lain di luar penelitian.

Sejalan dengan Teori Determinisme Teknologi oleh Marshall McLuhan dimana inti gagasan teori ini ialah bahwa kehidupan manusia, secara khusus sosial interaksi ditentukan oleh jenis dan perkembangan teknologi yang digunakan oleh manusia itu sendiri (Nurudin, 2017). Penemuan serta perkembangan teknologi pada determinisme teknologi adalah faktor yang mengubah kebudayaan manusia (McLuhan, 2003)

Seperti halnya dalam penelitian ini penggunaan smartphone yang intens membuat anggota keluarga melakukan phubbing terhadap satu sama lain dimana (Irawati dan Nurmina, 2020) menyatakan bahwasanya phubbing banyak dilakukan dalam aktivitas sehari-hari khususnya di rumah seperti saat berkumpul bersama anggota keluarga di ruang tamu, di meja makan saat makan bersama, dan bahkan di dapur. Selain intensitas komunikasi berkurang, anak juga menjadi lebih pasif dan enggan bercerita mengenai segala hal kepada orang tuanya dan hanya menanggapi dan merespon seadanya (Prabandari dan Rahmiaji, 2019).

Berdasarkan hasil penelitian, kebijakan di rumah aja pada masa pandemi Covid-19 membuat kegiatan menjadi serba teknologi yang mengakibatkan peningkatan penggunaan internet, salah satunya Kota Jakarta yang memiliki pengguna internet terbesar. Ini memunculkan rangsangan baru dalam pikiran, pemahaman, atau mindset bahwa kegiatan yang sebelumnya tidak menyertakan teknologi sepenuhnya berbeda pada masa pandemi Covid-19 yang mana keadaan ini mewajibkan seseorang untuk beradaptasi dengan teknologi sehingga menunjukkan adanya perubahan tingkah laku terhadap lingkungannya yaitu kecenderungan penggunaan 
teknologi yang intens dilakukan setiap harinya selama kegiatan dirumah saja berlangsung yang berpotensi mengabaikan sekitarnya.

Sesuai dengan pendapat McLuhan bahwasanya media adalah faktor utama yang paling mempengaruhi hal lainnya (Nurudin, 2017). Dalam penelitian ini teknologi smartphone diyakini memberikan dampak perubahan terhadap cara masyarakat beraktivitas. Bahwa peralatan yang diciptakan manusia, selanjutnya membentuk perubahan perilaku pada diri mereka sendiri. Kemudian, secara implikatif teknologi menjadi penggerak peradaban manusia karena ketergantungan mereka terhadap teknologi (Mulyadi, 2020).

Kemudian, pemikiran dari teori Derterminisme Teknologi ini antara lain, 1). Adanya penemuan baru atau inovasi dibidang teknologi memberikan dampak perubahan pada budaya, 2). Cara komunikasi yang berubah dan membentuk keeksistensian kehidupan manusia, dan 3). McLuhan menyatakan bahwa "We shape our tools, and they in turn shape us" (kitalah yang membentuk alat yang kita perlukan dan sekarang alat itulah yang membentuk diri kita) (Nurudin, 2017). Terlihat jelas pada pernyatan dengan skor tertinggi X yakni "saya menunda beberapa aktivitas ketika saya menggunakan smartphone selama pandemi Covid-19" dimana ketergantungan dari teknologi smartphone telah membentuk dan merubah perilaku masyarakat kota Jakarta menjadi sering menunda aktivitas yang harusnya segera dilakukan sesuai dengan poin ketiga dari kerangka urutan pemikiran teori determinisme teknologi.

Teknologi telah membentuk cara pikir, tingkah laku dalam masyarakat dan bergerak dari satu era teknologi ke sebuah era selanjutnya dalam kehidupan manusia (McLuhan, 2003). Berdasarkan hasil penelitian, kebijakan dirumah saja dimasa pandemi Covid-19 membuat kegiatan menjadi serba teknologi yang mengakibatkan peningkatan penggunaan smartphone dan internet serta perangkat penunjang pekerjaan lainnya seperti laptop dan tablet. Kemajuan teknologi pada masa pandemi Covid-19 ini membentuk sebuah perubahan masyarakat dikarenakan teknologi berhasil membentuk cara pikir mereka, dan tingkah laku dalam budaya masyarakat dipengaruhi berdasarkan teknologi yang ia gunakan.

Kian hari, setelah masuknya internet dan perkembangannya yang begitu pesat maka teknologi media baru pun ikut jauh berkembang yang dalam kehidupan sehari-hari yang sudah menjadi teman setia. Media interaktif lahir dari perkembangan media baru dimana hasil dari perkembangan pesat sebuah teknologi multimedia. internet dan berhasil membuat seluruh orang dari berbagai belahan di dunia terhubung dengan mudah (Febriana, 2018). Salah satu media baru yang muncul karena inovasi teknologi adalah smartphone, benda kecil satu ini meringankan segala pekerjaan manusia sekaligus dapat memberikan hiburan bagi penggunanya yang sekarang sudah menjadi kebutuhan dikehidupan sehari-hari. Sesuai dengan pernyataan McLuhan bahwa "the new need and the new technological response are born of our embrace of the already existing technology" yakni bahwa kebutuhan dan respons kita terhadap teknologi baru lahir dari rangkulan kita terhadap teknologi yang sudah ada (McLuhan, 2003).

Dahulu sebelum teknologi, interaksi sosial antar sesama manusia terjalin dengan baik, namun semenjak adanya teknologi manusia cenderung bergantung pada teknologi baru seperti komputer, laptop, smartphone, internet. Hasil penelitian ini menyatakan bahwa Perilaku Phubbing mempengaruhi kurangnya Intensitas Komunikasi Keluarga pada masa pandemi Covid-19 sesuai dengan penelitian terdahulu oleh Novita Sirupang pada tahun 2020 bahwa tanpa disadari penggunaan teknologi smartphone ini mengurangi kuantitas, kualitas dan hubungan secara langsung dengan anggota keluarga, serta memiliki dampak lain dimana anggota keluarga sebagai lawan bicara merasa tidak dihargai yang mana hal ini juga sesuai dengan konsekuensi negatif dari penggunaan teknologi yang buruk oleh masyarakat, bukan dari sifat teknologi itu sendiri (Nugroho, 2020). Determinisme teknologi percaya jika manusia dibentuk dan dipengaruhi besar oleh perkembangan teknologi dan terutama media adalah alat atau sarana sangat berpengaruh dalam menentukan bagaimana sebuah teknologi berhasil mengubah cara pandang manusia berpikir, merasa, dan melakukan tindakan tertentu (Nurudin, 2017).

McLuhan menyatakan bahwa di samping manfaat teknologi, terdapat dampak negatif terhadap kehidupan manusia. Di satu sisi, teknologi memberikan kemudahan dalam meningkatkan capaian dan memperluas jangkauan keterbatasan kemampuan manusia. Di sisi lain, penggunaan teknologi memungkinkan manusia teramputasi dari tugas dan fungsinya, baik secara fisik maupun mental yang menyebabkan hilangnya harkat (dehumanisasi) sebagai makhluk sosial (McLuhan, 2003). Sesuai dengan hasil penelitian dimana perilaku Phubbing berpengaruh terhadap berkurangnya Intensitas Komunikasi Keluarga karena masa pandemi Covid-19 menjadikan orang tergantung dengan smartphone dan internet hingga mereka acuh terhadap sekitarnya.

Hakikinya manusia adalah makhluk sosial yang ingin selalu berinteraksi dengan satu sama lain. Intensitas komunikasi keluarga yang baik ialah dimana tingkat keteraturan anggota keluarga untuk berkomunikasi untuk saling berbicara, mengobrol atau bertukar pesan untuk menyampaikan sebuah informasi atau perkembangan satu sama lain terjaga dengan baik walaupun ditengah kesibukan masing-masing. Keluarga harus menjaga 
hubungan baik agar tetap harmonis. Namun dengan ketergantungan teknologi mengubah perilaku seseorang menjadi phubbing yakni mengabaikan lawan bicara dalam sebuah percakapan dan lebih berfokus kepada smartphone dibandingkan berinteraksi dan memperhatikan lawan bicara yang akhirnya mengakibatkan berkurangnya intensitas komunikasi dalam keluarga.

Kondisi lingkungan sosial menentukan perkembangan teknologi, dimana pengenalan dan penggunaan teknologi baru adalah hasil dari tatanan sosial. Teknologi di satu sisi dan aspek sosial di sisi lain, dan masyarakat dimodelkan oleh perubahan teknis seperti media baru khususnya smartphone telah mengubah sifat dan cara individu serta masyarakat dalam bertindak (Hauer, 2017)

Teknologi membuat dampak perubahan cara masyarakat dalam beraktivitas (Mulyadi, 2020). Namun saat ini, masyarakat harus menyesuaikan dan beradaptasi dengan teknologi dan inovasi baru sesuai dengan keadaan lingkungan yang ada hal ini tentu mempengaruhi sikap masyarakat dalam menggunakan teknologi (Nugroho, 2020). Perubahan sikap ini membuat pembatasan kegiatan manusia dalam praktik sosialnya karena teknologi mengambil alih fungsikan sehingga membuat manusia menjadi budak dari teknologi itu sendiri. Salah satunya dengan adanya perilaku phubbing yang menyebabkan orang sulit terlepas akan kecanggihan teknologi dan mengabaikan lingkungan sekitarnya khususnya dalam lingkungan keluarga selama pandemi Covid-19 yang mengharuskan masyarakat mengandalkan teknologi untuk berbagai aktivitas.

\section{SIMPULAN DAN SARAN}

\section{Kesimpulan}

Berdasakan hasil dan pembahasan yang telah peneliti paparkan di atas, dapat disimpulkan bahwa kemajuan teknologi smartphone selain membawa manfaat bagi kehidupan namun juga turut serta memberikan dampak negatif seperti halnya perilaku phubbing dimana para pelaku phubbing lebih mementingkan smartphonenya dibanding membangun sebuah percakapan dengan lawan bicara.

Berdasarkan hasil penelitian, perilaku phubbing berpengaruh terhadap berkurangnya intensitas komunikasi keluarga pada masa pandemi Covid-19 di kota Jakarta dan jawaban responden pada setiap pernyataan indikator variabel $X$ yaitu perilaku phubbing menyatakan bahwa perilaku phubbing secara parsial berpengaruh positif dan signifikan terhadap variabel $Y$ yaitu berkurangnya Intensitas Komunikasi Keluarga.

Variabel perilaku phubbing (X) memperoleh Nilai R Square 0,477 berarti 47,7\%, nilai tersebut menunjukkan bahwa perilaku phubbing secara parsial berpengaruh positif dan signifikan terhadap berkurangnya intensitas komunikasi keluarga pada masa pandemi Covid-19 di kota Jakarta sebesar 47,7\%.

Saran

Saran akademis bagi peneliti selanjutnya adalah peneliti selanjutnya dapat meneliti permasalahan ini melalui pendekatan kualitatif dimana peneliti bisa menggali lebih dalam mengenai faktor atau penyebab lainnya yang mempengaruhi Intensitas Komunikasi Keluarga. Disisi lain, Saran praktis dari penelitian ini adalah untuk keluarga di kota Jakarta, diharapkan membatasi penggunaan smartphone dalam keseharian agar komunikasi tatap muka antar anggota keluarga tetap terjaga dengan baik. Adapun Saran sosial pada penelitian ini adalah untuk para pengguna smartphone, diharapkan memberikan pengetahuan tentang dampak positif dan negatif dari penggunaan smartphone sehingga masyarakat lebih bijak untuk peduli terhadap lingkungan sekitar dan menghargai lawan bicara dengan cara memperhatikan dan mengapreasiasi mereka ketika mereka sedang berbicara.

\section{REFERENSI}

APJII. (2020). Buletin APJII. Asosiasi Penyelenggara Jasa Internet Indonesia, p. 1. Retrieved from https://apjii.or.id/content/read/104/503/BULETIN-APJII-EDISI-74---November-2020

APJII. (2020). Laporan Survei Internet APJII 2019 - 2020. In Asosiasi Penyelenggara Jasa Internet Indonesia (Vol. 2020). Retrieved from https://apjii.or.id/survei

Bacigalupe, G., \& Bräuninger, I. (2017). Emerging Technologies and Family Communication: The Case of International Students. Contemporary Family Therapy, 39(4), 289-300. https://doi.org/10.1007/s10591017-9437-7

Chotpitayasunondh, V., \& Douglas, K. M. (2018). Measuring phone snubbing behavior: Development and validation of the Generic Scale of Phubbing (GSP) and the Generic Scale of Being Phubbed (GSBP). Computers in Human Behavior, 88(June), 5-17. https://doi.org/10.1016/j.chb.2018.06.020

CNBC Indonesia. (2020). APJII: Efek WFH, Trafik Penggunaan Internet Ritel Naik 20\%. Retrieved February 9, 2021, from https://www.cnbcindonesia.com/tech/20200416154547-39-152424/apjii-efek-wfh-trafikpenggunaan-internet-ritel-naik-20 
Devito, J. A. (2011). Komunikasi Antar Manusia Edisi Kelima. Jakarta: Karisma Publishing Group.

Dwijayanti, M., Fauzan, L., \& Flurentin, E. (2021). Fenomena Phone Snubbing pada Siswa Menengah Pertama. Jurnal Pembelajaran, Bimbingan, Dan Pengelolaan Pendidikan, 1(3), 170-177. https://doi.org/10.17977/um065v1i32021p170-177

Febriana, A. I. D. (2018). Determinasi Teknologi Komunikasi Dan Tutupnya Media Sosial Path. LONTAR: Jurnal IImu Komunikasi, 6(2), 86. https://doi.org/10.30656/lontar.v6i2.948

Fitriana, Ahmad, A., \& Fitria. (2020). Pengaruh Penggunaan Gadget Terhadap Perilaku Remaja Dalam Keluarga. Psikoislamedia Jurnal Psikologi, Universitas Syah Kuala, Banda Aceh, 5(2), 182-194. Retrieved from https://jurnal.ar-raniry.ac.id/index.php/Psikoislam/article/download/7898/5390

Hanika, I. M. (2015). Fenomena Phubbing di Era Milenia (Ketergantungan Seseorang pada Smartphone terhadap Lingkungannya). Interaksi: Jurnal IImu Komunikasi, 4(1), 42-51. https://doi.org/10.14710/interaksi.4.1.4251

Hauer, T. (2017). Technological Determinism and New media. 2(2), 1-4.

Ihsan, D. N. (2020). Libur Panjang Malah Sibuk Main HP, Awas Dampak Phubbing. Retrieved March 19, 2021, from solopos.com website: https://www.solopos.com/libur-panjang-malah-sibuk-main-hp-awas-dampakphubbing-1088919

Irawati, A. N., \& Nurmina. (2020). Perbedaan Perilaku Phubbing Pada Dewasa Awal Dalam Situasi Hubungan Keluarga, Hubungan Pertemanan, dan Hubungan Percintaan di Kota Bukittinggi. Jurnal Proyeksi, 15(2), 141-150. Retrieved from http://jurnal.unissula.ac.id/index.php/proyeksi/article/view/11179/4500

Kaddi, S. M., Lestari, P., \& Adrian, D. (2020). Komunikasi Keluarga Dalam Pencegahan Coronavirus Disease 2019. Jurnal IImu Komunikasi, 18(1), 63. https://doi.org/10.31315/jik.v18i1.3701

Karadağ, E., Tosuntaş, Ş. B., Erzen, E., Duru, P., Bostan, N., Şahin, B. M., ... Babadağ, B. (2015). Determinants of phubbing, which is the sum of many virtual addictions: A structural equation model. Journal of Behavioral Addictions, 4(2), 60-74. https://doi.org/10.1556/2006.4.2015.005

Kemkominfo, R. (2019). Survei penggunaan Teknologi informasi dan Komunikasi DKI Jakarta. 17.

Kriyantono, R. (2014). Teknik Praktis Riset Komunikasi. Jakarta: Prenadamedia Group.

Kuncara, T., Nugroho, T. P., Aryati, D., Thahar, E. A., \& Ramadhan, A. R. (2020). Prediksi Ekonomi Indonesia Pasca Covid-19. Surabaya: CV. Jakad Media Publishing.

Kuswanti, A., Muqsith, M. A., Zainal, A. G., \& Oktarina, S. (2020). Manajemen Komunikasi Keluarga Saat Pandemi COVID-19. SALAM: Jurnal Sosial Dan Budaya Syar-I, 7(8), 707-722. https://doi.org/10.15408/sjsbs.v7i8.15959

Mahmudah, Nurfalah, F., \& Lestari, A. D. (2020). Efektivitas Komunikasi Keluarga Dalam Membentuk Keluarga Sakinah (Studi Fenomenologi Keluarga di Griya Lobunta Lestari Cirebon). Signal, 8(1), 79-88. Retrieved from http://jurnal.unswagati.ac.id/index.php/Signal

Maulana, Y. (2020). Berlebihan Pakai Gadget Selama Pandemi, Gangguan Cemas di RSJ Meningkat. Retrieved April 19, 2021, from health.detik.com website: https://health.detik.com/berita-detikhealth/d5204481/berlebihan-pakai-gadget-selama-pandemi-gangguan-cemas-di-rsj-meningkat

McLuhan, M. (2003). Understanding Media. The Extensions of Man. Critical Edition (edited by W. Terrence Gordon). California: Gingko Press.

Mulyadi. (2020). Antara Teknologi dan Teologi: Theopanoptik dalam Pendisiplinan Aktor di Perpustakaan. Depok: Rajawali Pers.

Munawaroh, N. L., \& Azizah, N. (2018). Disharmoni Keluarga Ditinjau dari Intensitas Komunikasi. KOMUNIKA: Jurnal Dakwah Dan Komunikasi, 12(2), 291-310. https://doi.org/10.24090/komunika.v12i2.1354

Nugroho, C. (2020). Cyber Society: Teknologi, Media Baru, dan Disrupsi Informasi. Jakarta: Kencana Prenadamedia Group.

Nurudin. (2017). Pengantar Komunikasi Massa. Jakarta: Rajawali Pers.

Prabandari, A. I., \& Rahmiaji, L. R. (2019). Komunikasi Keluarga dan Penggunaan Smartphone Oleh Anak. Interaksi Online, 7(3), 224-237.

Prabowo, T. T. (2020). Memperebutkan Ruang Publik Virtual: Literasi, Hoax, dan Perdamaian. Yogyakarta: Zahir Publishing.

Sebayang, R. (2020). Di Tengah Pandemi, Penggunaan Teknologi Meningkat Pesat. Retrieved April 6, 2021, from cnbcindonesia.com website: https://www.cnbcindonesia.com/tech/20200723190647-37-175009/ditengah-pandemi-penggunaan-teknologi-meningkat-pesat

Sirupang, N., Arsyad, M., \& Supiyah, R. (2020). Dampak “Phubbing” Terhadap Keharmonisan Keluarga Di Keluharan Kadia Kecamatan Kadia Kota Kendari. Jurnal Neo Societal, 5(2), 200-211.

Sugiyono. (2014). Metode Penelitian Kuantitatif, Kualitatif, dan R \& D. Bandung: Alfabeta. 
Sujarweni, V. W. (2014). SPSS Untuk Penelitian. Yogyakarta: Pustaka Baru Press.

Suprayitno, A., \& Wahyudi, W. (2020). Pendidikan Karakter di Era Milenial. Yogyakarta: Penerbit Deepublish.

Turner, L. H., \& West, R. L. (2018). Perspectives On Family Communication Fifth Edition. New York: McGraw-Hill Higher Education.

Williams, B. K., \& Sawyer, S. C. (2015). Using Information Technology: A Practical Introduction To Computers \& Communications 11th Edition. New York: McGraw-Hill Higher Education.

https://doi.org/10.4324/9780203391228_chapter_8 